\title{
Predation and physical environment structure the density and population size structure of zebra mussels
}

\author{
Rahmat Naddafi ${ }^{1}$, Kurt Pettersson ${ }^{2}$, AND Peter Eklöv ${ }^{3}$ \\ Department of Ecology and Evolution/Limnology, Evolutionary Biology Centre, Uppsala University, \\ Norbyvägen 18 D, SE-75 236 Uppsala, Sweden
}

\begin{abstract}
The zebra mussel (Dreissena polymorpha) provides one example of successful invaders in novel environments. However, little attention has been devoted to exploring the factors regulating zebra mussel density and population size structure at the local scale. We tested effects of physicochemical factors and fish predation on the density of zebra mussels at several sites and between years in a natural lake. Water depth and roach (Rutilus rutilus) density were the most important variables affecting local zebra mussel density. Substrate was also an important factor but affected Dreissena density only at the shallowest depth examined $(2 \mathrm{~m})$, which also supported a large population of the mussels. Mean shell length of Dreissena increased with water depth. Our results indicate that predation pressure, intraspecific competition, and food limitation might be responsible for variation in zebra mussel density and population size structure in space and time and that fish predation might have strong top-down effects on zebra mussel populations.
\end{abstract}

Key words: invasive species, zebra mussel, predation, water depth, population size structure, local scale.

Understanding the factors that determine the distribution, abundance, and structure of species is a major goal of ecological research. Understanding these factors is particularly important when studying exotic species because they can exploit available niche opportunities in the new habitat (Shea and Chesson 2002), become widespread and dominant in the community (Colautti and MacIsaac 2004), change foodweb dynamics, and strongly influence the structure of the invaded community (MacIsaac 1996b, Karatayev et al. 1997, Naddafi et al. 2007a).

The zebra mussel (Dreissena polymorpha) is one of the most successful invading species in European and North American lakes (MacIsaac 1996b, Naddafi et al. 2009). It is capable of monopolizing a considerable part of available energy through high filtering capacity and selective feeding on high-quality phytoplankton (MacIsaac 1996b, Mackie and Schloesser 1996, Naddafi et al. 2007b). Zebra mussels cause considerable economic loss to electrical power plants and water treatment facilities, and can reduce plankton biomass, increase water clarity, alter phyto-

\footnotetext{
${ }^{1}$ Present address: Department of Natural Resources, 106 Rice Hall, Cornell University, Ithaca, New York 14850 USA. E-mail: rn99@cornell.edu

${ }^{2}$ E-mail addresses: kurt.pettersson@ebc.uu.se

3 peter.eklov@ebc.uu.se
}

plankton species composition, increase macrophyte distribution, eradicate native bivalves, compete with resident species, modify nutrient cycling, change seston stoichiometry, alter energy pathways, and affect foodweb dynamics (MacIsaac 1996b, Karatayev et al. 1997, Naddafi et al. 2008).

The magnitude of the effects of zebra mussels, like those of other invading species, is strongly related to population size. Thus, identification of the factors that influence zebra mussel density can provide a basis for understanding the capacity of populations to expand and to affect the ecology and economy of invaded aquatic ecosystems. Moreover, the length-frequency distribution (size structure) of zebra mussel populations can provide information on growth and survival of individual cohorts (Griffiths et al. 1991, Mackie 1991) and valuable insight into the effects of this exotic species on ecosystem functioning (e.g., Naddafi et al. 2008).

Physicochemical properties of the recipient environment, such as surface area, depth, substrate, Ca concentration, $\mathrm{pH}$, temperature, and trophic status, have been suggested as main factors constraining density, growth, and invasion success of zebra mussels at regional (among-lake) scales (Ramcharan et al. 1992b, Mellina and Rasmussen 1994, Sprung 1995, Naddafi 2007, Whittier et al. 2008), whereas biotic factors, such as fish predation, have been 
suggested as secondary factors (Thorp et al. 1998). McMahon (1991) proposed fishes as the most active predators of settled zebra mussels, but only a handful of studies have indicated the potential of fish predation to control invasion success and density of exotic mussels (Eggleton et al. 2004, Bartsch et al. 2005, Watzin et al. 2008). The relative importance of biotic interactions and the physical environment to successful invasion is poorly understood (Havel et al. 2005).

Food availability, larval supply, and physical disturbance, which can vary along a depth gradient, can affect size structure of zebra mussel populations (MacIsaac 1996a). Thus, a change in zebra mussel size structure along a depth gradient might be expected. Little attention has been devoted to the factors regulating zebra mussel density and size structure at the local (within-lake) scale (but see Casagrandi et al. 2007). We asked: 1) Which factors regulate zebra mussel density at the local scale? and 2) How does Dreissena size structure change as a function of water depth? We investigated the density of zebra mussels in relation to limnological variables and fish abundance. We assessed spatial and temporal variability in size structure along a depth gradient $(2,4,6$, and $8 \mathrm{~m})$ at sites with hard and soft substrates in Lake Erken, Sweden, in 2004 and 2005. We found that both physical environment and predation pressure contribute to the differences in density and size distribution at the local scale.

\section{Methods}

\section{Study area}

We conducted our study in Lake Erken, a moderately deep, meso-eutrophic (total P [TP]: 24-51 $\mu \mathrm{g} / \mathrm{L}$ ], dimictic lake in southeastern Sweden (lat $59^{\circ} 51^{\prime} \mathrm{N}$, long $\left.18^{\circ} 35^{\prime} \mathrm{E}\right)$. The lake is covered by ice from December through April. It has a surface area of $\sim 24 \mathrm{~km}^{2}$, a mean depth of $9 \mathrm{~m}$, and a maximum depth of $21 \mathrm{~m}$. Most of the shoreline is stony and rocky, and the littoral substrate is composed of bedrock, stone, cobble, gravel, sand, mud, and other sediments. Vegetation consists mostly of Phragmites australis in shallow areas. Zebra mussels invaded Lake Erken in mid-1975, spread rapidly, and have been a dominant part of the biota since 1976 (Naddafi et al. 2007a).

The western part of Lake Erken is more eutrophic, less clear, and shallower and supports higher densities of macrophytes and earlier blooms of cyanobacteria than the middle and eastern parts of the lake. Most of the inlets flow through the western part, and the outlet is in the eastern part. Primary production in the eastern part tends to increase with increasing westerly wind intensity (KP, unpublished data).

\section{Mussel and water sampling: spatial variation}

We sampled 6 sites across 3 parts of the lake (eastern part: sites A and B, middle part: sites C and F, western part: sites $\mathrm{D}$ and $\mathrm{E}$ ) to assess spatial variation in density of zebra mussels. Sites A, D, and F had relatively soft substrate composed of sand and sandmud sediments. Sites B, C, and E had hard substrates, composed of a mixture of rock, stone, cobble, and gravel. We established 1 transect line perpendicular to the shoreline at each of the 6 sites along a depth gradient in June 2005. We determined sampling locations by driving a boat along each line and placing a weighted buoy in the water at suitable depth measured by an echo sounder. The geographical location of each sampling site was determined with a Global Positioning System (GPS).

Mussel samples were collected by SCUBA divers at each site at 2, 4, 6, and $8 \mathrm{~m}$ depths along each line in June 2005. Based on visual observation, zebra mussels were rare at depths $>8 \mathrm{~m}$. At each sampling location, divers randomly placed a $0.25-\mathrm{m}^{2}$ square frame on the bottom and collected all hard materials and aggregations of mussels within the frame area by hand. Then, they removed the top $5 \mathrm{~cm}$ of sediment within the frame area and passed the sediments through a 0.5$\mathrm{mm}$ sieve. Triplicate frame samples were collected at random locations at each depth with $\sim 2 \mathrm{~m}$ between replicates. Dreissena collected from each frame sample were placed in separate buckets filled with lake water and were transported to the laboratory (Naddafi et al. 2009).

In the laboratory, we detached mussels from their substrate by severing their byssal threads with a scalpel and counted them to estimate zebra mussel density (number $/ \mathrm{m}^{2}$ ). We froze mussels collected from each frame separately. We thawed the samples and randomly chose $\sim 1 / 3$ of the mussels in each sample and measured shell lengths with a vernier caliper $( \pm 0.05 \mathrm{~mm})$.

We estimated the quantity (chlorophyll $a$ [Chl $a]$ content) and quality (seston stoichiometry) of food available to zebra mussels and other limnological variables from monthly water samples taken from each of the 6 sampling sites at depths of 2, 4, 6, and $8 \mathrm{~m}$ from June to November 2005. We collected 4 (1/ depth) 2-L samples from $\sim 25 \mathrm{~cm}$ above the sediment surface at each site. We divided each water sample into 5 aliquots for measurement of: 1) TP; 2) Chl $a$; 3) $\mathrm{NH}_{4}{ }^{+}-\mathrm{N}, \mathrm{NO}_{3}{ }^{-}-\mathrm{N}, \mathrm{NO}_{2}{ }^{-}-\mathrm{N}$, and $\mathrm{PO}_{4}{ }^{3-}-\mathrm{P}$; 4) particulate $\mathrm{C}(\mathrm{PC})$ and particulate $\mathrm{N}(\mathrm{PN})$; and 5) particulate 
$\mathrm{P}(\mathrm{PP})$. We prepared the aliquots for PN, PC, and PP by filtering $145 \mathrm{~mL}$ of water onto precombusted GF/C filters. Methods for analysis of $\mathrm{Chl} a$ and stoichiometric analysis of water samples are described in Naddafi et al. (2008). Mean bottom dissolved $\mathrm{O}_{2}$ concentration ranged from 8.7 to $9.4 \mathrm{mg} / \mathrm{L}$, and temperature ranged from $16.2^{\circ} \mathrm{C}$ to $17.8^{\circ} \mathrm{C}$ among depths in all sites during June through September 2005 (KP, unpublished data).

\section{Fish density}

We estimated the density of benthic fish by sampling with standard benthic multimesh gillnets of a type used for monitoring fish populations in Nordic countries (NORDIC gill nets). The nets are $30 \mathrm{~m}$ long $\times 1.5 \mathrm{~m}$ deep with 12 mesh sizes ranging from 5 to $55 \mathrm{~mm}$ (knot-to-knot) following a geometric series (Appleberg 2000). In August 2005, we set 12 gillnets perpendicular to the shoreline along the transect line at all sites $(2$ nets per site: 1 net covered depths from $2-4 \mathrm{~m}$ and 1 net covered depths from 6-8 m) before dusk (1800-2000 h) and hauled them in the next morning (0600-0800 h). August is a recommended sampling time for fish in Nordic lakes because no freshwater species spawn at this time and each species has normal activity; i.e., no one species is over- or underrepresented in the catch (Appleberg 2000). We sampled each site on 2 nights. We expressed fish density as number of fish/gillnet (catch per unit of effort [CPUE]). We counted all species of fish and calculated total fish density per site as the mean CPUE for the 2 gillnets. Previous fish sampling at the same sites in August 2004 (54 efforts) and June 2005 (24 efforts) (KP, unpublished data) lent support to our results (see below).

Among fish caught by gillnets, only roach (Rutilus rutilus), bream (Abramis brama), and white bream (Blicca bjoerkna) are known to prey on Dreissena (Nagelkerke and Sibbing 1996). The main part of the diet of roach $>180 \mathrm{~mm}$ total length (TL) consists of Dreissena (Karatayev et al. 1997). Roach of this size feed actively on zebra mussels under experimental conditions (Naddafi et al. 2007a), and we included them in our model. Bream, white bream, pike (Esox lucius), pikeperch (Stizotedion lucioperca), and bleak (Alburnus alburnus) are relatively rare in Lake Erken, and we assumed they did not affect zebra mussel density. Besides roach, the most common fish in the lake were perch (Perca fluviatilis) and ruffe (Gymnocephalus cernuus). These 2 species do not feed on zebra mussels, and we did not consider them in our analysis.

\section{Mussel and water sampling: temporal variation}

We sampled 2 sites in the eastern part of the lake (site A, soft substrate; site B, hard substrate) in June 2004 and 2005 to assess temporal (interannual) variation in zebra mussel density and size distribution. The sampling procedure was similar in both years except that we did not sample mussels at a depth of $8 \mathrm{~m}$ in 2004. Therefore, we compared only data from 2, 4, and $6 \mathrm{~m}$ between 2004 and 2005.

\section{Correlation}

We averaged monthly water-chemistry data and food quantity and quality variables over depths for use in the model. We used averaged data because environmental variables affect zebra mussel densities during the ice-free period. Thus, long-term averaged values might be more relevant than a snapshot of them in June. We calculated Pearson correlation coefficients between environmental variables (Naddafi et al. 2009). When variables were collinear $(p<0.05)$, we used only one of the collinear variables in our analysis. We found strong correlations among seston C:N ratio, PC, and PN $(r$ $=0.82)$; seston $\mathrm{C}: \mathrm{P}$ and $\mathrm{N}: \mathrm{P}$ ratios $(r=0.99)$; seston $\mathrm{C}: \mathrm{P}$ ratio and $\mathrm{PP}(r=0.82) ; \mathrm{Chl} a$ and $\mathrm{NH}_{4}{ }^{+}-\mathrm{N}(r=$ $0.88) ; \mathrm{PO}_{4}{ }^{3-}-\mathrm{P}, \mathrm{PN}$, and $\mathrm{PC}(r=0.88)$. Seston $\mathrm{C}$ :nutrient ratio is important in herbivore growth (e.g., Hessen et al. 2002), so we retained it instead of $\mathrm{PC}$ and $\mathrm{PN}$, and we retained C:P ratio instead of $\mathrm{N}: \mathrm{P}$ ratio and $\mathrm{PP}$. We retained $\mathrm{Chl} a$ instead of $\mathrm{NH}_{4}{ }^{+}-\mathrm{N}$ because phytoplankton (measured as $\mathrm{Chl}$ a) is the main food resource for mussels (Macisaac 1996b). After excluding PN and PC, we entered $\mathrm{PO}_{4}{ }^{3-}$-P concentration into our analysis. We considered $\mathrm{TP}, \mathrm{TN}, \mathrm{NO}_{3}{ }^{-}-\mathrm{N}$, and $\mathrm{NO}_{2}{ }^{-}-\mathrm{N}$ concentrations because they are important for growth of phytoplankton and because Dreissena density and lake trophic status are significantly related (Naddafi 2007). We also included 2 important physical variables, substrate (Mellina and Rasmussen 1994) and depth (MacIsaac 1996b), in our model.

\section{Statistical analysis}

We used multiple regressions to determine the factors that best predicted zebra mussel density. We regressed zebra mussel density against substrate, depth, nutrient concentrations (TP, $\mathrm{NO}_{3}{ }^{-}-\mathrm{N}, \mathrm{NO}_{2}{ }^{-}$ $\mathrm{N}, \mathrm{PO}_{4}{ }^{3-}-\mathrm{P}$, and $\mathrm{TN}$ ), seston $\mathrm{C}: \mathrm{P}$ and $\mathrm{C}: \mathrm{N}$ molar ratios, Chl $a$, and roach density. We identified the subset of predictors that provided the best fit to the observed data with the Akaike information criterion (AIC) (Quinn and Keough 2002) for each model as: 
TABLE 1. Best-supported linear regression models for factors affecting zebra mussel density in Lake Erken. $\triangle A I C$ $=$ difference between the AIC (Akaike Information Criterion) score for that model and the minimum AIC (346.3).

\begin{tabular}{lcccl}
\hline \hline \multicolumn{1}{c}{ Model } & $r^{2}$ & $F$ & $p$ & $\Delta$ AIC \\
\hline Roach density, depth & 0.45 & 8.7 & 0.002 & 0 \\
Roach density, depth, substrate & 0.47 & 5.8 & 0.005 & 1.4 \\
Roach density, depth, substrate, & 0.47 & 4.1 & 0.01 & 3.4 \\
$\quad$ total N & & & & \\
Roach density, depth, substrate, & 0.47 & 3.2 & 0.03 & 5.4 \\
$\quad$ total N, total P & & & & \\
Roach density & 0.24 & 7.1 & 0.01 & 5.8 \\
$\begin{array}{l}\text { Depth, substrate } \\
\text { Depth }\end{array}$ & 0.28 & 4 & 0.03 & 6.7 \\
\hline
\end{tabular}

$$
A I C=n\left(\ln \left[S S_{\text {residual }}\right)+2(p+1)-n \ln (n)\right.
$$

where, $n$ is the number of observations, $S S_{\text {residual }}$ is the sum of squares of residuals, and $p$ is the number of predictors included in a specific model. Smaller values of AIC indicate more parsimonious models (Quinn and Keough 2002). We also computed the differences in AIC $(\triangle A I C)$ among candidate models according to Burnham and Anderson (2002; $\triangle A I C=$ $\left.A I C_{i}-A I C_{\mathrm{min}}\right)$. Models with $\triangle A I C>10$ have essentially no support, models with $\triangle A I C$ between 4 and 7 have considerably less support, and models with $\triangle A I C<2$ have substantial support (Burnham and Anderson 2002). We present only models with $\triangle A I C<7$.

We used separate 1-way analyses of variance (ANOVA) to compare zebra mussel density among substrate types for each depth. We used a 2-way ANOVA to test the effects of site, depth, and site $\times$ depth interaction on zebra mussel density and shell length. We used a 2-way repeated-measures ANOVA with time as the repeated measure and site and depth as between-subjects factors to test for differences in zebra mussel density and shell length between years. We followed all analyses by a Tukey's test for multiple comparisons. We used linear regression to analyze the relationships between roach and zebra mussel biomasses and between zebra mussel density and size structure. We tested all data for homogeneity of variances and $\log (x)$-transformed them if necessary. Statistical significance was set at $p<0.05$.

\section{Results}

The multiple regressions yielded 7 models with $\triangle A I C<7$ (Table 1 ). The model with roach density and depth as predictors provided the best fit to the
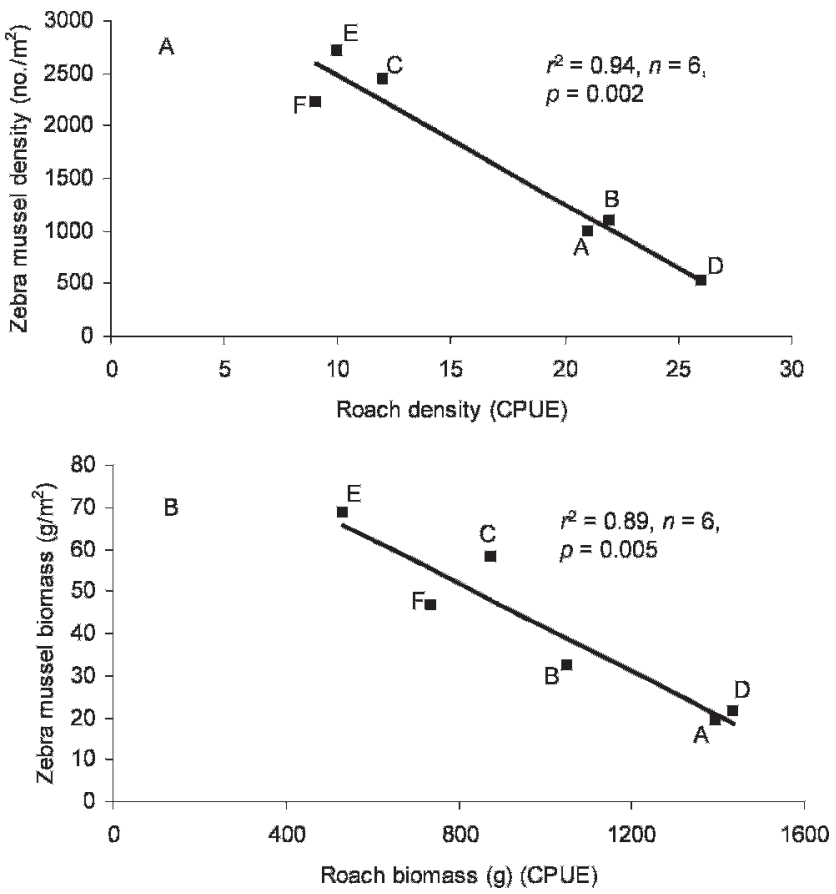

FIG. 1. Regressions of mean zebra mussel density (number $/ \mathrm{m}^{2}$ ) on mean roach density (catch per unit effort [CPUE]) (A) and mean zebra mussel biomass $\left(\mathrm{g} / \mathrm{m}^{2}\right)$ on mean roach biomass (g) (CPUE) (B) in Lake Erken in 2005. Letters next to each point indicate the site from which the samples were taken.

observed data (mussel density $=5351 \pm 766$ [mean \pm $\mathrm{SE}]-122 \pm 340$ [roach density] $-331 \pm 117$ [depth]; $r^{2}$ $=0.45, p=0.002, n=24)$. The model with roach density, depth, and substrate as predictors also was plausible $(\triangle A I C<2)$. Roach density was negatively related to zebra mussel density (Fig. 1A), and roach biomass was negatively related to Dreissena biomass (Fig. 1B).

Zebra mussel shell length was negatively related to zebra mussel density (Fig. 2). The effect of substrate on zebra mussel density was analyzed separately for each depth because both depth and substrate were selected by the model. At $2 \mathrm{~m}$, zebra mussel density was higher on hard than on soft substrates (1-way ANOVA, $\left.F_{1,16}=5.4, p<0.05\right)$. Zebra mussel density did not differ between substrate types at $4 \mathrm{~m}\left(F_{1,16}=\right.$ $0.05, p=0.8), 6 \mathrm{~m}\left(F_{1,16}=2.4, p=0.14\right)$, or $8 \mathrm{~m}\left(F_{1,16}=\right.$ $0.6, p=0.45)$. The density of zebra mussels differed among sites (Table 2, Fig. 3A) and depths (Table 2, Fig. 3B), and the effect of site on zebra mussel density differed among depths (significant site $\times$ depth interaction; Table 2). On average, density of zebra mussels was lowest at site D (Fig. 3A) and depth $6 \mathrm{~m}$ (Fig. 3B). Site and depth significantly affected shell length (Table 2). On average, zebra mussels were largest at site D (Fig. 3C) and depth $6 \mathrm{~m}$ (Fig. 3D). The 


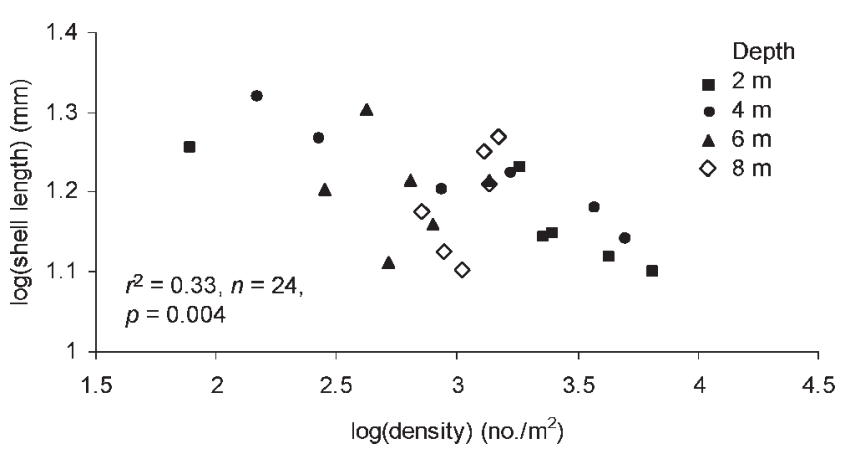

FIG. 2. The relationship between mean zebra mussel density and mean shell length at each depth in Lake Erken.

size of mussels increased with increasing depth (Tukey's test, $p<0.01$ ), but no significant difference in mussel shell length was found between 6 and $8 \mathrm{~m}$ (Tukey's test, $p>0.05$; Fig. 3D).

Dreissena density changed significantly between years ( $p<0.01$; Table 3$)$. Zebra mussel density in the eastern part (sites A and B) of Lake Erken decreased from $1982 \pm 362$ individuals (ind.) $/ \mathrm{m}^{2}$ in 2004 to $1072 \pm 925 \mathrm{ind} / \mathrm{m}^{2}$ in 2005 . The time $\times$ site $\times$ depth interaction effect showed that the change in zebra mussel density over time was not related to site and depth. Zebra mussel density did not differ between sites A and B (Table 3). Across both years, Dreissena density varied among depths, and the effect of site on zebra mussel density differed among depths, as indicated by the significant site $\times$ depth interaction (Table 3).

Dreissena shell length varied over time (Table 3). Moreover, all interactions involving time and the effects of site and depth on shell length were significant $(p<0.01$; Table 3$)$. Thus, shell length differed temporally and spatially among sites and depths. Of the classes with $>4 \%$ of mussels represented, the most abundant size classes at site A were 3 to $13 \mathrm{~mm}$ in 2004 and 9 to $18 \mathrm{~mm}$ in 2005 . The most abundant size classes at site B were 4 to $13 \mathrm{~mm}$ in 2004 and 10 to $19 \mathrm{~mm}$ in 2005 (Fig. 4). Mean ( \pm SE) shell length of the mussel population was $9.3 \pm 0.22$ at site
A and $13.2 \pm 0.17$ at site B in 2004 and $14.5 \pm 0.22$ at site A and $16.0 \pm 0.24$ at site B in 2005 .

\section{Discussion}

Roach density was one of the most important variables that negatively affected local zebra mussel density in Lake Erken. Roach are active consumers of zebra mussels (Stańczykowska 1977, Karatayev et al. 1997, Molloy et al. 1997), and the negative relationship between mussel and roach densities and biomasses (Fig. 1A, B) indicate that fish predation might regulate the Dreissena population in Lake Erken. Westerbom et al. (2006) suggested that roach predation might affect population dynamics of blue mussel (Mytilus edulis) in some areas of northeastern Baltic Sea. Reports from North American waters also support our conclusion. The abundance of the exotic mussel, Musculista senhousia, in a southern California bay was largely constrained by a small number of native molluscivores (Reusch 1998). Fish predation is proposed to control zebra mussel populations in Lake Champlain, USA (Watzin et al. 2008), in eastern North America (French 1993), and in coastal wetlands (Bowers and de Szalay 2007). Bioenergetic modelling suggested that fish predation might decelerate zebra mussel invasion success and spread in southern US waters where fish growth rate and metabolic demands are high (Eggleton et al. 2004).

Depth and substrate were the physical factors that best predicted local Dreissena density. On average, density of zebra mussels was highest at $2 \mathrm{~m}$ depth in Lake Erken (Fig. 3B), possibly because the substrate at that depth consists of rocks that provide surface area (space) for mussel attachment. Colonization of the sandy substrate in Lake Erken by zebra mussels is associated with conversion of some part of the sediments to shell gravel, as in other lakes (e.g., Berkman et al. 1998, Strayer and Malcom 2006). Water depth also affected density, biomass, and population structure of zebra mussels living on submerged macrophytes in Lake Balaton, Hungary (Muskó and Bakó 2005). The maximum density of zebra mussels in

TABLE 2. Results of 2-way analysis of variance for the effects of site, water depth, and their interaction on Dreissena density and shell length in Lake Erken.

\begin{tabular}{|c|c|c|c|c|c|c|c|}
\hline \multicolumn{4}{|c|}{ Dreissena density } & \multicolumn{4}{|c|}{ Dreissena shell length } \\
\hline Site & 5 & 5.3 & $<0.01$ & Site & 5 & 7 & $<0.001$ \\
\hline Depth & 3 & 9.3 & $<0.001$ & Depth & 3 & 7.8 & $<0.001$ \\
\hline Site $\times$ depth & 15 & 3.1 & $<0.01$ & Site $\times$ depth & 15 & 27.8 & $<0.001$ \\
\hline Error & 48 & & & Error & 7226 & & \\
\hline
\end{tabular}



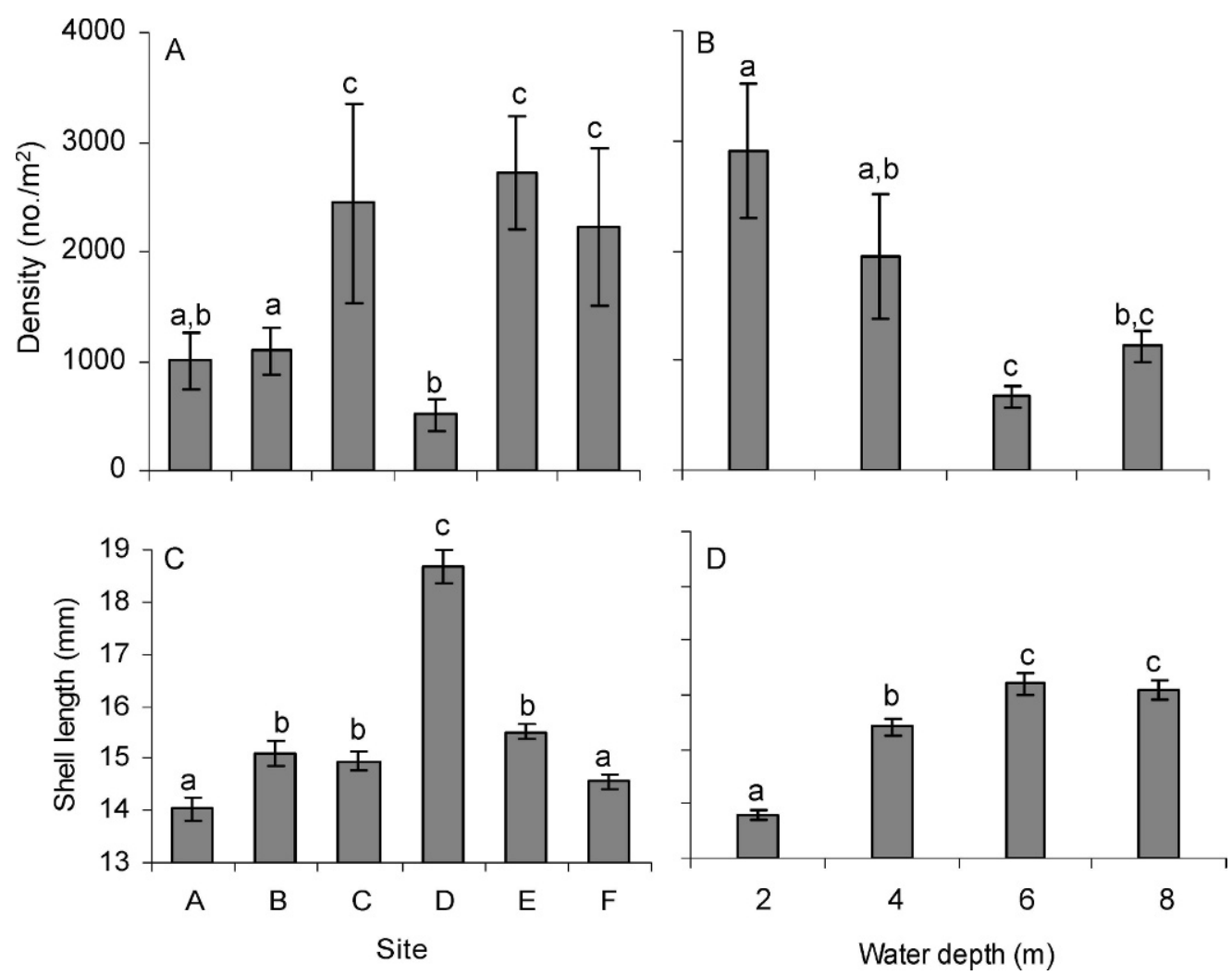

Fig. 3. Mean ( \pm 1 SE) zebra mussel density at each site (A) and depth (B) and mean shell length at each site (C) and depth (D). Within each panel, bars with the same lowercase letter are not significantly different $(p>0.05$, Tukey's test).

most European lakes and reservoirs occurs at depths from 1 to $5 \mathrm{~m}$ (Karatayev et al. 1998). Zebra mussel distribution in the profundal zone of lakes usually is constrained by low $\mathrm{O}_{2}$ concentration and lack of suitable substrate (Karatayev et al. 1998). However, where no such limitation is present, maximum density of Dreissena can be observed in deeper zones. For example, maximum density of zebra mussels was recorded at $18 \mathrm{~m}$ in Lake Garda, Italy, and between 5 and $15 \mathrm{~m}$ in Bodensee, Germany (Karatayev et al. 1998), and zebra mussels were found in high density (1500 to $32,500 / \mathrm{m}^{2}$ ) on sand and sand-mud sediments at $14 \mathrm{~m}$ depth in western Lake Erie (Berkman et al. 1998). All sampling sites and depths in our study had sufficient suitable substrates and $\mathrm{O}_{2}$ supply to support zebra mussels. Thus, the results of our study

TABLE 3. Results of 2-way repeated measures analysis of variance for the effect of time, site, depth, and their interactions on Dreissena density and shell length in Lake Erken.

\begin{tabular}{|c|c|c|c|c|c|c|}
\hline \multirow[b]{2}{*}{ Source } & \multicolumn{3}{|c|}{ Dreissena density } & \multicolumn{3}{|c|}{ Dreissena shell length } \\
\hline & $\mathrm{df}$ & $F$ & $p$ & $\mathrm{df}$ & $F$ & $p$ \\
\hline \multicolumn{7}{|l|}{ Between subjects } \\
\hline Site & 1 & 2.6 & 0.14 & 1 & 45.3 & $<0.001$ \\
\hline Depth & 2 & 20.8 & $<0.001$ & 2 & 74.5 & $<0.001$ \\
\hline Site $\times$ depth & 2 & 5.7 & $<0.05$ & 2 & 31.1 & $<0.001$ \\
\hline Error & 12 & & & 12 & & \\
\hline \multicolumn{7}{|l|}{ Within subjects } \\
\hline Time & 1 & 16.3 & $<0.01$ & 1 & 176.2 & $<0.001$ \\
\hline Time $\times$ site & 1 & 2.5 & 0.14 & 1 & 26.6 & $<0.001$ \\
\hline Time $\times$ depth & 2 & 3.2 & 0.07 & 2 & 8.7 & $<0.01$ \\
\hline Time $\times$ site $\times$ depth & 2 & 1.3 & 0.31 & 2 & 12.0 & $<0.01$ \\
\hline Error & 12 & & & 12 & & \\
\hline
\end{tabular}



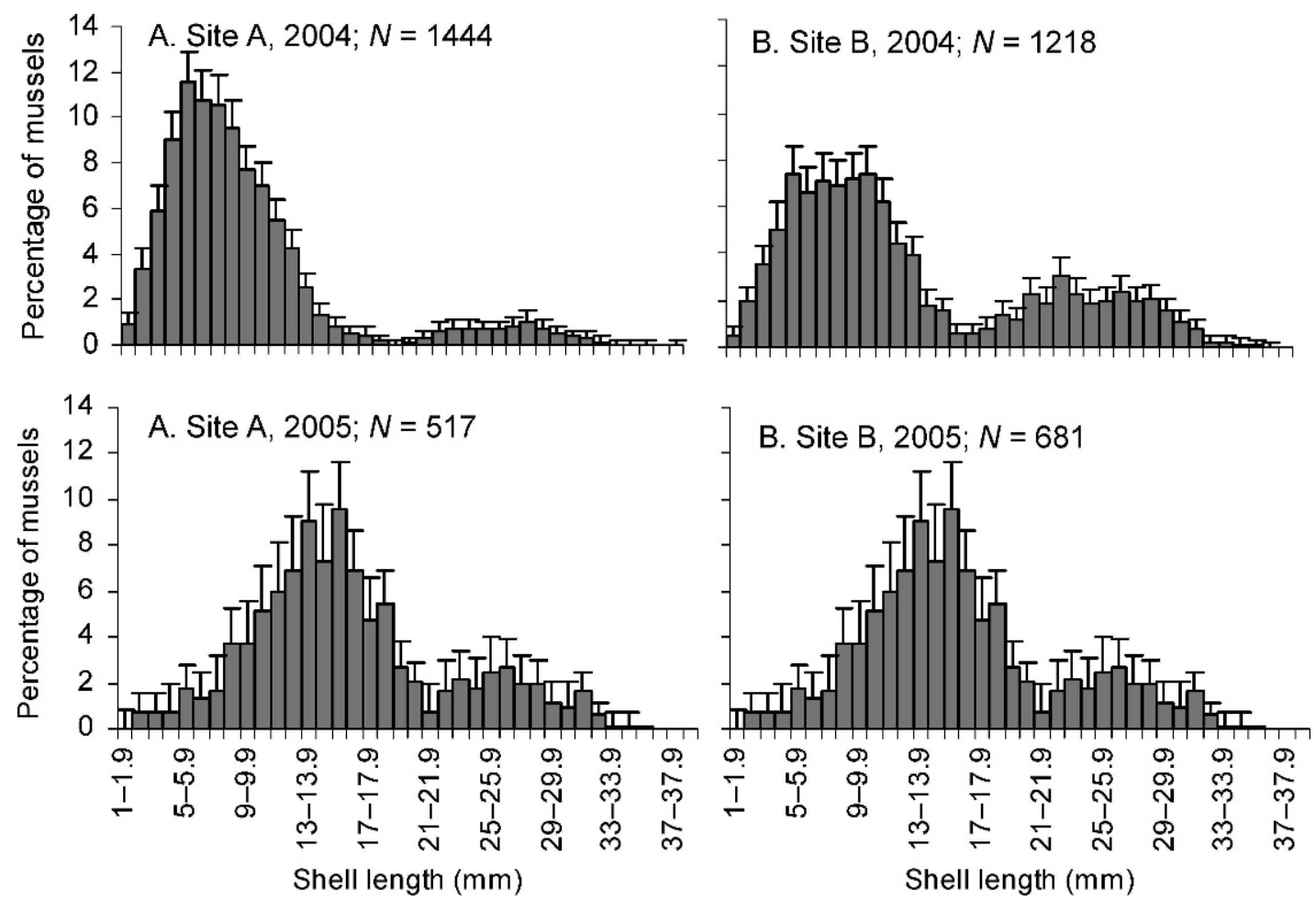

FIG. 4. Mean (+ 95\% CI) percentages of zebra mussels in 1-mm size classes at site A (sandy substrate) in 2004 (A), site B (rocky and cobble substrates) in 2004 (B), site A in 2005 (C), and site B in 2005 (D). Zebra mussels were collected from 2-, 4-, and 6-m depths. $N=$ number of individuals measured.

indicate that biotic factors, such as predation, and physical factors, such as depth and substrate, can determine zebra mussel density at the local scale.

Dreissena shell length increased with depth in the current study. Shells of 2 species of mussels, Lampsilis radiata luteola and Anodontoides ferussacianus, were longer in deeper water in Long Lake, USA (Cvancara 1972). This pattern also has been observed in very deep lakes. For instance, large zebra mussels $(>25 \mathrm{~mm})$ were present at offshore locations with $\geq 37 \mathrm{~m}$ depth but were absent or underrepresented on rocks collected at nearshore sites near Middle Sister Island in western Lake Erie, USA (MacIsaac 1996a). In contrast, Mills et al. (1999) found no relationship between dreissenid mean size and water depth from collections at $10-\mathrm{m}$ intervals from 15 to $85 \mathrm{~m}$ in Lake Ontario, USA, in either 1992 or 1995. The direction of changes in population structure of mussels along a depth gradient in lakes can be related to changes in food limitation, habitat disturbance, and recruitment limitation with depth (Menge 1991, MacIsaac 1996a). For example, Nalepa et al. (1996) found that mean shell length of Dreissena declined as water-column Chl a decreased between 1990 and 1994 in Lake St. Clair (see also Hunter and Simons 2004). The negative effect of Dreissena density on shell length (our study) and condition factor (RN, W. Goedkoop [Swedish University of Agricultural Sciences], U. Grandin (Swedish University of Agricultural Sciences), and PE, unpublished data) indicate that intraspecific competition might cause food limitation and, thus, the slower growth rates and smaller shell lengths of mussels in shallower area of lakes.

In our study, Dreissena density in the eastern basin of Lake Erken decreased between 2004 and 2005, and the most abundant size group shifted from the 3- to 13-mm shell length class in 2004 to the 9- to 19-mm shell length class in 2005. A strong 2003 year-class appears to have been followed by a weak 2004 yearclass. Large interannual variation in recruitment is common in zebra mussel populations because of a range of long-term factors (Ramcharan et al. 1992a, Strayer and Malcom 2006, Casagrandi et al. 2007). For example, high predation pressure can drive zebra mussel population dynamics in lakes (Burla and Ribi 1998, Strayer and Malcom 2006). Dreissena $<15 \mathrm{~mm}$ shell length were consumed by roach $>180 \mathrm{~mm}$ TL (Karatayev et al. 1997, Naddafi et al. 2007a). However, like other fishes, roach can be gape-limited (e.g., McMahon 1991, Tucker et al. 1996) and might prefer smaller prey (zebra mussels) (but see Prejs et al. 1990) because more effort might be required to handle 
larger mussels. The preference of round goby (Neogobius melanostomus) for small Dreissena appears to change zebra mussel population size structure (Ray and Corkum 1997).

Optimal foraging theory suggests that predators select prey sizes or prey types that maximize net energy intake. Larger mussels should provide higher energy content, but the ratio between costs and benefits (the net feeding efficiency) of prey is determined mainly by handling cost (Nagelkerke and Sibbing 1996). Small mussels probably have lower crushing resistance and weaker byssal threads than do large ones. Therefore, they would provide higher net energy intake. However, an increase in predator size is associated with increased gape size, which might lead to selection of larger prey (Prejs et al. 1990, Nagelkerke and Sibbing 1996). Roach are assumed to select small mussels when different sizes of mussels are available to minimize intake of shell material (shell weight minimization hypothesis; Bustnes and Erikstad 1990) and to decrease handling cost (Westerbom et al. 2006).

Nevertheless, a recently developed demographic model predicted that size-selective and nonselective predation can change the population dynamics of zebra mussels in terms of abundance (density and biomass) and size structure (Casagrandi et al. 2007). Density of zebra mussels was lowest at site D (Fig. 2A) where density of roach is highest and at depth $6 \mathrm{~m}$ where the mussels are larger than at other depths, probably because of size-selective predation. These results lend support to our conclusion that predation from roach is an important factor regulating local density of zebra mussels. However, the home range and spatial distribution of roach in Lake Erken is unknown and warrants further investigation. Hence, our results contribute to the growing evidence that fish predation might have strong top-down effects on zebra mussel populations. Top-down effects might moderate the effects of zebra mussels on lake ecosystems. However, our study is only observational, and other factors than roach predation might be responsible for the patterns reported here.

The physical environment can constrain the success of invasive species (Moyle and Light 1996). Baltz and Moyle (1993) suggested that the success of an invading species in a water body is dependent on abiotic variables rather than on biotic resistance of the invaded community. Habitat disturbance and surface area also might affect spatial variability of the exotic species at the local scale (Elton 1958, Naddafi 2007). Habitat disturbance can increase resource availability and opportunity for successful invasion (Elton 1958), but MacIsaac (1996b) found an inverse relationship between the frequency of habitat disturbance and abundance of zebra mussels in an exposed rocky area. Large lakes are more likely to support greater density and diversity of invasive species because of higher propagule pressure and more suitable habitats (Havel et al. 2005) and are more likely to have more variable local density of the exotic species because of great local habitat heterogeneity and variable local predation pressure (Naddafi 2007, our study) than small lakes. The response of a species to spatial and temporal variation in the resources, natural enemies, and the physical environment might determine its ability to invade and grow in the novel ecosystem.

\section{Acknowledgements}

We are grateful to Anna Gustafsson, Björn Mattsson, and Nazila H. Koupayeh for assistance in the laboratory and in the field. We also thank Teresa Newton, 2 anonymous referees, and Lars Rudstam for helpful comments on an earlier version of the manuscript. This study was financed by the Swedish Research Council and the Malméns Foundation to RN and the Swedish Research Council for Environment, Agricultural Science, and Spatial Planning (Formas) to PE.

\section{Literature Cited}

Appleberg, M. 2000. Swedish standard methods for sampling freshwater fish with multi mesh gillnets. Fiskeriverket Information 2000:1. Fiskeriverket, Goteborg, Sweden.

BAltz, D. M., AND P. B. Moyle. 1993. Invasion resistance to introduced species by a native assemblage of stream fishes. Ecological Applications 3:246-255.

Bartsch, M. R., L. A. Bartsch, and S. Gutreuter. 2005. Strong effects of predation by fishes on an invasive macroinvertebrate in a large floodplain river. Journal of the North American Benthological Society 24:168-177.

Berkman, P. A., M. A. Haltuch, E. Tichich, D. W. Garton, G. W. Kennedy, J. E. Gannon, S. D. MacKey, J. A. Fuller, AND D. L. Liebenthal. 1998. Zebra mussels invade Lake Erie muds. Nature 393:27-28.

Bowers, R. W., AND F. A. DE Szalay. 2007. Fish predation on zebra mussels attached to Quadrula quadrula (Bivalvia: Unionidae) and benthic molluscs in a Great Lakes costal wetland. Wetlands 27:203-208.

Burla, H., AND G. RiBI. 1998. Density variation of the zebra mussel Dreissena polymorpha in Lake Zurich, from 1976 to 1988. Aquatic Sciences 60:145-156.

Burnham, K. P., And D. R. Anderson. 2002. Model selection and multimodel inference: a practical informationtheoretic approach. $2^{\text {nd }}$ edition. Springer-Verlag, New York.

Bustnes, J. O., and K. E. ERIKstad. 1990. Size selection of common mussels, Mytilus edulis, by common eiders, Somateria mollissima: energy maximization or shell 
weight minimization? Canadian Journal of Zoology 68: 2280-2283.

Casagrandi, R., L. Mari, and M. Gatto. 2007. Modelling the local dynamics of the zebra mussel (Dreissena polymorpha). Freshwater Biology 52:1223-1238.

Colautti, R. I., And H. J. MacIsaAc. 2004. A neutral terminology to define invasive species. Diversity and Distribution 10:135-141.

Crancara, A. M. 1972. Lake mussel distribution as determined with SCUBA. Ecology 53:154-157.

Eggleton, M. A., L. E. Miranda, And J. P. KirK. 2004. Assessing the potential for fish predation to impact zebra mussels (Dreissena polymorpha): insight from bioenergetics models. Ecology of Freshwater Fish 13: 85-95.

ELton, C. S. 1958. The ecology of invasion by animals and plants. Methuen, London, UK.

French, J. R. P. 1993. How well can fishes prey on zebra mussels in Eastern North America? Fisheries 18(6):13-19.

Griffiths, R. W., D. W. Schlosser, J. H. Leach, and W. P. KovalaK. 1991. Distribution and dispersal of the zebra mussel (Dreissena polymorpha) in the Great Lakes Region. Canadian Journal of Fisheries and Aquatic Sciences 48: 1381-1388.

Havel, J. E., J. B. Shurin, AND J. R. JonEs. 2005. Environmental limits to a rapidly spreading exotic cladoceran. Ecoscience 12:376-385.

Hessen, D. O., P. Færøvig, And T. Andersen. 2002. Light, nutrients, and $\mathrm{P}: \mathrm{C}$ ratios in algae: grazer performance related to food quality and quantity. Ecology 83: 1886-1898.

Hunter, R. D., AND K. A. SimOns. 2004. Dreissenids in Lake St. Clair in 2001: evidence for population regulation. Journal of Great Lakes Research 30:528-537.

Karatayev, A. Y., L. E. Burlakova, and D. K. Padilla. 1997. The effects of Dreissena polymorpha (Pallas) invasion on aquatic communities in Eastern Europe. Journal of Shellfish Research 16:187-203.

Karatayev, A. Y., L. E. Burlakova, and D. K. Padilla. 1998. Physical factors that limit the distribution and abundance of Dreissena polymorpha (Pall.). Journal of Shellfish Research 17:1219-1235.

MACISAAC, H. J. 1996a. Population structure of an introduced species (Dreissena polymorpha) along a wave-swept disturbance gradient. Oecologia (Berlin) 105:484-492.

MacIsaAC, H. J. 1996b. Potential abiotic and biotic impacts of zebra mussels on the inland waters of North America. American Zoology 36:287-299.

Mackie, G. L. 1991. Biology of the exotic zebra mussel, Dreissena polymorpha, in relation to native bivalves and its potential impact in Lake St. Clair. Hydrobiologia 219: 251-268.

Mackie, G. L., And D. W. Schloesser. 1996. Comparative biology of zebra mussels in Europe and North America: an overview. American Zoology 36:244-258.

McMahon, R. F. 1991. Mollusca: Bivalvia. Pages 315-399 in J. H. Thorp and A. P. Covich (editors). Ecology and classification of North American freshwater invertebrates. Academic Press, New York.

Mellina, E., And J. B. Rasmussen. 1994. Patterns in the distribution and abundance of zebra mussel (Dreissena polymorpha) in rivers and lakes in relation to substrate and other physicochemical factors. Canadian Journal of Fisheries and Aquatic Sciences 51:1024-1036.

Menge, B. A. 1991. Relative importance of recruitment and other causes of variation in rocky intertidal community structure. Journal of Experimental Marine Biology and Ecology 146:69-100.

Mills, E. L., J. R. Chrisman, B. Baldwin, R. W. Owens, R. O'Gorman, T. Howell, E. F. Roseman, and M. K. Raths. 1999. Changes in the dreissenid community in the lower Great Lakes with emphasis on southern Lake Ontario. Journal of Great Lakes Research 25:187-197.

Molloy, D. P., A. Y. Karatayev, L. E. Burlakova, D. P. Kurandina, And F. Laruelle. 1997. Natural enemies of zebra mussels: predators, parasites, and ecological competitors. Reviews in Fisheries Science 5:27-97.

Moyle, P. B., AND T. Light. 1996. Fish invasions in California: do abiotic factors determine success? Ecology 77: 1666-1670.

MusKó, I. B., AND B. BAKÓ. 2005. The density and biomass of Dreissena polymorpha living on submerged macrophytes in Lake Balaton (Hungary). Archiv für Hydrobiologie 162:229-251.

NADDAFI, R. 2007. The invasion of the zebra mussel - effects on phytoplankton community structure and ecosystem function. PhD Dissertation, Uppsala University, Uppsala, Sweden. Acta Universitatis Upsaliensis. Digital comprehensive summaries of Uppsala dissertations from the Faculty of Science and Technology 361.

Naddafi, R., P. EkLÖV, and K. PetTersson. 2007a. Non-lethal predator effects on the feeding rate and prey selection of the exotic zebra mussel Dreissena polymorpha. Oikos 116: 1289-1298.

Naddafi, R., P. EklÖV, ANd K. Pettersson. 2009. Stoichiometric constraints do not limit successful invaders: zebra mussels in Swedish lakes. PLoS ONE 4:e5345.

Naddafi, R., K. Pettersson, And P. Eklöv. 2007b. The effect of seasonal variation in selective feeding by zebra mussels (Dreissena polymorpha) on phytoplankton community composition. Freshwater Biology 52:823-842.

Naddafi, R., K. Pettersson, and P. Eklöv. 2008. Effects of the zebra mussel, an exotic freshwater species, on seston stoichiometry. Limnology and Oceanography 53: 1973-1987.

Nagelkerke, L. A. J., And F. A. SibBing. 1996. Efficiency of feeding on zebra mussel (Dreissena polymorpha) by common bream (Abramis brama), white bream (Blicca bjoerkna), and roach (Rutilus rutilus): the effects of morphology and behavior. Canadian Journal of Fisheries and Aquatic Sciences 53:2847-2861.

Nalepa, T. F., D. J. Hartson, G. W. GosteniK, D. L. Fanslow, AND G. A. LANG. 1996. Changes in the freshwater mussel community of Lake St. Clair: from Unionidae to Dreissena polymorpha in eight years. Journal of Great Lakes Research 22:354-369. 
Prejs, A., K. Lewandowski, And A. StańczyKowska-Piotrowska. 1990. Size-selective predation by roach (Rutilus rutilus) on zebra mussels (Dreissena polymorpha): field studies. Oecologia (Berlin) 83:378-384.

Quinn, G. P., And M. J. KeOugh. 2002. Experimental design and data analysis for biologists. Cambridge University Press, Cambridge, UK.

Ramcharan, C. W., D. K. Padilla, and S. I. Dodson. 1992a. A multivariate model for predicting population fluctuations of Dreissena polymorpha in North American Lakes. Canadian Journal of Fisheries and Aquatic Sciences 49: 150-158.

Ramcharan, C. W., D. K. Padilla, and S. I. Dodson. 1992b. Models to predict potential occurrence and density of the zebra mussel, Dreissena polymorpha. Canadian Journal of Fisheries and Aquatic Sciences 49:2611-2620.

RAY, W. J., AND L. D. CoRKUM. 1997. Predation of zebra mussels by round gobies, Neogobius melanostomus. Environmental Biology of Fishes 50:267-273.

Reusch, T. B. H. 1998. Native predators contribute to invasion resistance to the non-indigenous bivalve Musculista senhousia in southern California, U.S.A. Marine Ecology Progress Series 170:159-168.

SheA, K., AND P. Chesson. 2002. Community ecology theory as a framework for biological invasions. Trends in Ecology and Evolution 14:170-176.

Sprung, M. 1995. Physiological energetics of the mussel Dreissena polymorpha in lakes: I. growth and reproductive effort. Hydrobiologia 304:117-132.
StAŃCZYKOWSKA, A. 1977. Ecology of Dreissena polymorpha (Pall.) (Bivalvia) in lakes. Polish Archive of Hydrobiology 24:461-530.

Strayer, D. L., AND H. M. Malcom. 2006. Long-term demography of a zebra mussel (Dreissena polymorpha) population. Freshwater Biology 51:823-842.

Thorp, J. H., M. D. Delong, And A. F. Casper. 1998. In situ experiments on predatory regulation of a bivalve mollusc (Dreissena polymorpha) in the Mississippi and Ohio rivers. Freshwater Biology 39:649-661.

Tucker, J. K., F. A. Cronin, D. W. Soergel, and C. H. Theiling. 1996. Predation on zebra mussels (Dreissena polymorpha) by common carp (Cyprinus carpio). Journal of Freshwater Ecology 11:363-372.

Watzin, M. C., K. Joppe-Mercure, J. Rowder, B. Lancaster, AND L. BRONSON. 2008. Significant fish predation on zebra mussels Dreissena polymorpha in Lake Champlain, U.S.A. Journal of Fish Biology 73:1585-1599.

Westerbom, M., A. Lappalainen, and O. Mustonen. 2006. Invariant size selection of blue mussels by roach despite variable prey size distributions. Marine Ecology Progress Series 328:161-170.

Whittier, T. R., P. L. Ringold, A. T. Herlihy, and S. M. PeIRSON. 2008. A calcium-based invasion risk assessment for zebra and quagga mussels (Dreissena spp.). Frontiers in Ecology and the Environment 6:180-184.

Received: 4 June 2009 Accepted: 21 December 2009 